\title{
PENGARUH PROFITABILITAS, STRUKTUR MODAL, UKURAN PERUSAHAAN DAN KEBIJAKAN DIVIDEN TERHADAP NILAI PERUSAHAAN
}

\section{Putu Hendra Sintyana ${ }^{1}$ \\ Luh Gede Sri Artini ${ }^{2}$}

${ }^{1,2}$ Fakultas Ekonomi dan Bisnis Universitas Udayana (Unud), Bali, Indonesia

e-mail: hendra.sintyana@yahoo.com

\begin{abstract}
ABSTRAK
Tujuan penelitian ini adalah untuk mengetahui pengaruh variabel profitabilitas, struktur modal, ukuran perusahaan dan kebijakan dividen terhadap nilai perusahaan. Penelitian ini dilakukan di Bursa Efek Indonesia pada tahun 2014-2016. Teknik pengambilan sampel menggunakan metode purposive sampling. Teknik analisis yang digunakan adalah regresi linier berganda. Berdasarkan hasil analisis ditemukan bahwa profitabilitas dan kebijakan dividen berpengaruh positif signifikan terhadap nilai perusahaan, sedangkan struktur modal dan ukuran perusahaan tidak berpengaruh terhadap nilai perusahaan. Manajemen perusahaan harus memperhatikan profitabilitas dan kebijakan dividen pada perusahaan serta faktor-faktor yang dapat mempengaruhi profitabiltas dan kebijakan dividen. Hal ini dikarenakan profitabilitas dan kebijakan dividen terbukti berpengaruh signifikan terhadap nilai perusahaan sehingga dapat memberikan sinyal bagi investor.
\end{abstract}

Kata kunci: nilai perusahaan, profitabilitas, struktur modal, ukuran perusahaan, kebijakan dividen

\begin{abstract}
The purpose of this study is to determine the effect of profitability variables, capital structure, firm size and dividend policy on corporate value. This research is conducted at Indonesia Stock Exchange in 2014-2016. The sampling technique used purposive sampling method. The analysis technique used is multiple linear regression. Based on the results of the analysis found that the profitability and dividend policy have a significant positive effect on firm value, while the capital structure and firm size does not affect the value of the company. Company management must pay attention to the profitability and dividend policy on the company and the factors that can affect profitability and dividend policy. This is because the profitability and dividend policy proved to have a significant effect on the value of the company so as to provide a signal for investors.
\end{abstract}

Keywords: company value, profitability, capital structure, firm size, dividend policy 


\section{PENDAHULUAN}

Manajemen keuangan memiliki tujuan memaksimumkan nilai dari perusahaan atau kemakmuran dari pemegang saham perusahaan. Wiagustini (2014:9) menyatakan bahwa memaksimalkan kemakmuran pemegang saham adalah tujuan yang tepat sebagai pedoman keputusan manajemen keuangan. Memaksimalkan nilai perusahaan tidak bisa disamakan dengan memaksimumkan profit dan laba perlembar saham (Earning per Share atau EPS), karena memaksimumkan profit dan EPS memiliki beberapa kelemahan.

Kelemahan memaksimumkan profit adalah tidak memperhatikan dimensi waktu. Kerugian perusahaan dapat terjadi karena memaksimumkan profit tanpa memperhitungkan tingkat risiko setiap alternatif. Kelemahan Memaksimumkan EPS adalah memusatkan pada EPS saat ini, tidak memperhatikan nilai waktu uang dan tidak memperhatikan faktor risiko (Wiagustini, 2014:10).

Perusahaan umumnya berusaha untuk mencapai tujuannya, baik tujuan jangka pendek yaitu memaksimalkan laba perusahaan maupun tujuan jangka panjang yaitu mampu meningkatkan nilai perusahaan dan mensejahterakan para pemegang saham. Menarik perhatian para investor terhadap perusahaan merupakan tujuan meningkatkan nilai perusahaan (Pramana dan Mustanda, 2016). Husnan dan Pudjiastuti (2012:7) mengartikan nilai perusahaan sebagai harga yang mampu dibayarkan oleh calon pembeli ketika perusahaan tersebut dijual. Perusahaan go public atau telah menawarkan saham ke publik maka nilai perusahaan diartikan sebagai persepsi seorang investor terhadap perusahaan itu sendiri. Investor dapat mempergunakan nilai perusahaan sebagai dasar untuk 
melihat kinerja perusahaan pada periode mendatang, dimana nilai perusahaan sering dikaitkan dengan harga saham. Investor akan memperoleh keuntungan apabila harga saham perusahaan tinggi. Menurut Wijaya dan Sedana (2015) nilai perusahaan dapat tercermin melalui harga saham suatu perusahan. Harga saham yang tinggi membuat ketertarikan investor akan semakin besar, karena nilai perusahaan yang tinggi mengindikasikan bahwa tingkat kemakmuran yang tinggi dari para pemegang saham dalam suatu perusahaan. Nilai perusahaan yang tinggi akan membuat rasa percaya seorang investor akan meningkat, baik itu kinerja perusahaan saat ini maupun pada prospek perusahaan dimasa depan.

Investor tertarik terhadap suatu perusahaan dapat terjadi karena informasi yang disampaikan dalam laporan keuangan perusahaan menunjukkan bahwa perusahaan memiliki prospek yang baikdi masa yang akan datang. Fenomena laporan keuangan yang dipublikasikan menunjukkan peran dari signaling theory. Signaling theory didasarkan pada asumsi bahwa informasi yang diterima oleh masing-masing pihak tidak sama. Signaling theory menunjukkan adanya asimetri informasi antara manajemen perusahaan dengan pihak-pihak yang berkepentingan dengan informasi. Manajer perlu memberikan informasi bagi pihak-pihak yang berkepentingan melalui penerbitan laporan keuangan. Signaling theory mengemukakan tentang bagaimana seharusnya sebuah perusahaan memberikan sinyal kepada pengguna laporan keuangan. Sinyal ini berupa informasi mengenai apa yang sudah dilakukan oleh manajemen untuk merealisasikan keinginan pemilik (Sinaga, 2014). 
Investor dapat mempergunakan nilai perusahaan sebagai dasar untuk menilai kinerja perusahaan di masa yang akan datang, nilai perusahaan ini sering dikaitkan dengan harga saham (Wijaya dan Panji, 2015). Nilai perusahaan dapat diukur menggunakan rasio price to book value (PBV). Brigham dan Houston (2015:152) menyatakan price to book value (PBV) adalah perbandingan antara harga saham dengan nilai buku per lembar saham. Semakin tinggi PBV maka semakin tinggi pula tingkat kemakmuran dari para pemegang saham yang merupakan tujuan utama suatu perusahaan. Rasio PBV dapat digunakan untuk semua jenis perusahaan sebab nilai buku dapat menjadi ukuran yang rasional untuk menilai perusahaan. Rasio PBV dapat digunakan untuk membandingkan perusahaan-perusahaan yang memiliki standar akuntansi yang sama dalam suatu sektor industri (Laksitaputri, 2012).

Menurut Wiagustini (2014:7) nilai perusahaan dapat dipengaruhi oleh keputusan manajemen keuangan meliputi keputusan pendanaan, keputusan investasi serta keputusan dividen. Keputusan investasi adalah keputusan keuangan yang berkaitan dengan aktivitas investasi dalam berbagai bentuk. Keputusan pendanaan merupakan keputusan keuangan yang berkaitan dengan aktivitas pembelanjaan atau pembiayaan investasi. Keputusan dividen adalah aktivitas keuangan yang berkaitan dengan distribusi laba yang diperoleh perusahaan. Keputusan-keputusan yang diambil dalam manajemen keuangan akan berpengaruh terhadap nilai perusahaan.

Penelitian ini menggunakan empat faktor yang akan diteliti pengaruhnya pada nilai perusahaan. Keempat faktor tersebut adalah profitabilitas, struktur 
modal, ukuran perusahaan dan kebijakan dividen. Empat faktor tersebut merupakan faktor internal perusahaan, kondisi internal perusahaan menggambarkan pengelolaan keuangan perusahaan tersebut dan adanya hasil penelitian sebelumnya yang berbeda sehingga menarik untuk diuji kembali pengaruh profitabilitas, struktur modal, ukuran perusahaan dan kebijakan dividen terhadap nilai perusahaan (Rassri dan Mustanda, 2013).

Faktor pertama yang dapat mempengaruhi nilai perusahaan adalah profitabilitas. Profitabilitas merupakan indikator yang dapat digunakan untuk menilai sebuah perusahaan, menunjukkan efektivitas sebuah perusahaan, serta memperlihatkan bagaimana manajemen perusahaan mengelola sumber daya yang dimiliki (Hestinoviana et al., 2013). Salah satu indikator yang mempengaruhi nilai perusahaan adalah sejauh mana perusahaan mampu menghasilkan keuntungan, sejalan dengan tujuan investor untuk berinvestasi, yaitu memperoleh keuntungan (Meidiawati dan Mildawati, 2016). Nilai perusahaan dapat pula dipengaruhi oleh besar kecilnya profitabilitas yang dihasilkan oleh perusahaan, profitabilitas yang tinggi akan memberikan prospek perusahaan yang baik sehingga meningkatkan permintaan saham. Permintaan saham yang meningkat mengakibatkan nilai perusahaan akan meningkat (Nurhayati, 2013). Profitabilitas diukur menggunakan return on asset (ROA). Penggunaan ROA dalam penelitian ini dikarenakan ROA dapat menunjukkan efisiensi operasional suatu perusahaan sehingga dapat menunjukkan kinerja perusahaan.

Hasil penelitian oleh Wahyuni dkk. (2013) menyatakan bahwa profitabilitas memiliki pengaruh positif signifikan terhadap nilai perusahaan. Kurnisari dan 
Wirastuti (2015) menyatakan bahwa profitabilitas berpengaruh positif dan signifikan terhadap nilai perusahaan. Sejalan dengan hasil penelitian sebelumnya, penelitian dari Sabrin et al. (2016) memperoleh hasil bahwa profitabilitas memiliki pengaruh positif signifikan terhadap nilai perusahaan. Hasil tersebut dikarenakan dengan pencapaian laba yang tinggi akan mengindikasikan perusahaan akan membagikan dividen, profitabilitas yang meningkat akan berdampak pada meningkatnya harga saham. Hasil berbeda ditunjukkan oleh penelitian Triagustina dkk. (2014) yang menunjukkan bahwa profitabilitas yang diproksikan dengan ROA memperoleh hasil profitabilitas berpengaruh negatif terhadap nilai perusahaan.

Faktor kedua dalam penelitian ini adalah struktur modal. Struktur modal mencakup mengenai keputusan pendanaan. Hal tersebut sangat penting bagi perusahaan untuk dapat menjalankan operasinya. Manajer dapat menggunakan utang sebagai sinyal yang lebih terpercaya untuk para investor. Ini karena perusahaan yang meningkatkan utang dapat dipandang sebagai perusahaan yang yakin dengan prospek perusahaan di masa yang akan datang. Jadi penggunaan utang merupakan tanda atau sinyal positif dari perusahaan yang dapat membuat para investor menghargai nilai saham lebih besar dari pada nilai yang tercatat pada neraca perusahaan, sehingga nilai perusahaan tinggi (Ayem dan Nugroho, 2016). Struktur modal merupakan gambaran atas pemakaian utang suatu perusahaan untuk membiayai kegiatan operasional perusahaan. Pengelolaan struktur modal sangatlah penting, sebab keputusan dalam penggunaan utang yang tinggi dapat meningkatkan nilai perusahaan yang dikarenakan adanya 
pengurangan atas pajak penghasilan (Suwardika dan Mustanda, 2017). Struktur modal dalam penelitian ini diukur menggunakan debt to equity ratio (DER). Penggunaan DER dikarenakan rasio ini dapat menunjukkan perimbangan antara utang dengan modal sendiri sehingga dapat menjadi informasi yang diperlukan investor.

Penelitian mengenai pengaruh struktur modal terhadap nilai perusahaan telah diteliti sebelumnya. Isola (2014) menyatakan bahwa struktur modal berpengaruh positif terhadap nilai perusahaan. Hasil serupa ditunjukkan oleh penelitian Gayatri dan Mustanda (2013) serta penelitian oleh Kausar et al. (2014) yang menunjukkan bahwa struktur modal berpengaruh positif signifikan terhadap nilai perusahaan. Sebaliknya, penelitian dari Chen dan Shun-Yu. (2011) bahwa struktur modal berpengaruh negatif terhadap nilai perusahaan, hasil tersebut didukung dengan pernyataan dari Sutrisno (2016). Dewi dan Badjra (2017) menemukan bahwa struktur modal berpengaruh negatif dan tidak signifikan terhadap nilai perusahaan.

Faktor ketiga dalam penelitian ini adalah ukuran perusahaan. ukuran perusahaan merupakan faktor penting dalam menentukan nilai perusahaan (Meidiawaati dan Mildawati, 2016). Ukuran perusahaan mencakup besar kecilnya sebuah perusahaan yang diperlihatkan oleh aset, jumlah penjualan, rata-rata total penjualan dan total aset rata-rata. Besar kecilnya ukuran perusahaan juga akan mempengaruhi perusahaan dalam kemudahan perolehan dana dari pasar modal, serta akan mempengaruhi kekuatan dari perusahaan dalam melakukan proses tawar-menawar di dalam kontrak keuangan antar perusahaan. Ukuran perusahaan 
yang besar dan terus tumbuh bias menggambarkan tingkat profit mendatang, kemudahan pembiayaan ini bisa mempengaruhi nilai perusahaan dan menjadi informasi yang baik bagi investor (Eko dkk., 2014). Ukuran perusahaan dalam penelitian ini diukur menggunakan total aset dengan tujuan mengurangi fluktuasi data yang berlebih. Total aset harus dihitung dengan logaritma natural (Ln) karena total aset perusahaan pada umumnya berjumlah milyaran sampai triliyunan sedangkan variabel lainnya dalam satuan persentase (Putra dan Lestari, 2016).

Novari dan Lestari (2016) dalam penelitiannya menunjukkan bahwa ukuran perusahaan berpengaruh positif signifikan terhadap nilai perusahaan. Obradovich dan Gill (2012) menunjukkan bahwa ukuran perusahaan berpengaruh positif terhadap nilai perusahaan. Hal tersebut juga didukung oleh penelitian Martini et al. (2014), Rizqia et al. (2013), dan Siahaan (2013) yang menunjukkan ukuran perusahaan berpengaruh positif signifikan terhadap nilai perusahaan. Sebaliknya, penelitian dari Winarto (2015) serta Suwardika dan Mustanda (2017) menunjukkan bahwa ukuran perusahaan tidak berpengaruh signifikan terhadap nilai perusahaan. Hasil penelitian Pantow dkk. (2015) menunjukkan bahwa ukuran perusahaan berpengaruh negatif dan tidak signifikan terhadap nilai perusahaan.

Faktor keempat yang mempengaruhi nilai perusahaan adalah kebijakan dividen. Kebijakan dividen adalah keputusan tentang seberapa banyak laba saat ini yang akan dibayarkan sebagai dividen daripada ditahan untuk diinvestasikan kembali dalam perusahaan. Besarnya dividen yang dibagikan kepada para pemegang saham akan menjadi daya tarik bagi pemegang saham karena sebagian 
investor cenderung lebih menyukai dividen dibandingkan dengan capital gain karena dividen bersifat lebih pasti. Perusahaan yang membagikan dividen akan menarik minat investor untuk menanamkan modalnya. Banyaknya investor yang membeli saham akan menaikkan harga saham sehingga meningkatkan nilai perusahaan (Putra dan Lestari, 2016). Kebijakan dividen dapat diukur dengan dividend payout ratio (DPR) yang membandingkan jumlah dividen yang dibayarkan dengan laba bersih yang diperoleh perusahaan.

Hasil penelitian oleh Priatinah dan Kusuma (2012) menyimpulkan bahwa investor yang menginvestasikan dananya akan melihat faktor pembayaran dividen oleh perusahaan. Ayem dan Nugroho (2016) menunjukkan bahwa kebijakan dividen berpengaruh positif dan signifikan terhadap nilai perusahaan. Hasil tersebut didukung hasil dari Priya dan Mohanasundari (2016) serta Winarto (2015). Hasil berbeda ditunjukkan Mardiyati dkk. (2012) serta Gayatri dan Mustanda (2014) yang menemukan bahwa kebijakan dividen tidak berpengaruh signifikan terhadap nilai perusahaan.

Signaling Theory menyatakan bahwa apapun informasi yang terjadi dari kondisi saham suatu perusahaan adalah selalu memberi efek bagi keputusan investor sebagai pihak yang menerima sinyal tersebut. Tanggapan para investor terhadap sinyal positif dan negatif sangat mempengaruhi kondisi pasar, investor akan bereaksi dengan berbagai cara dalam menanggapi sinyal tersebut (Fahmi 2016:295). Menurut Hanafi (2016:316) jika manajer mempunyai keyakinan bahwa prospek perusahaan baik, dan ingin agar harga saham meningkat, perlu 
mengkomunikasikan hal tersebut kepada investor dengan memberikan sinyal yang dapat dipercaya (credible).

Menurut Brigham and Houston (2015:187) informasi asimetris merupakan suatu kondisi di mana manajer memiliki informasi yang berbeda (lebih baik) tentang prospek perusahaan dibandingkan dengan yang dimiliki pihak luar atau investor. Sinyal merupakan suatu tindakan yang diambil oleh manajemen suatu perusahaan memberikan petunjuk kepada investor tentang bagaimana manajemen menilai prospek perusahaan tersebut. Tindakan yang dilakukan manajemen perusahaan akan menunjukkan sinyal bahwa suatu perusahaan memiliki prospek yang baik ataupun buruk.

Pada dasarnya sebuah perusahaan mempunyai tujuan untuk memperoleh laba atas kegiatan operasionalnya. Van Horne dan Wachowicz (2012:4) menyebutkan dengan memaksimalkan laba perusahaan, seorang manajer dapat terus menunjukkan peningkatan laba hanya dengan menerbitkan saham dan menggunakan hasilnya untuk berinvestasi dalam Treasury bill (T-bill), hal tersebut dapat menyebabkan turunnya laba per lembar saham atau earning per share (EPS). Tujuan utama sebuah perusahaan adalah memaksimumkan kekayaan atau nilai perusahaan (value of firm). Nilai perusahaan tercermin dari nilai sekarang atas semua keuntungan yang diperoleh perusahaan yang diharapkan di masa depan. Fahmi (2016:4) menyatakan memaksimumkan nilai perusahaan adalah bagaimana perusahaan atau pihak manajemen perusahaan mampu memberikan nilai yang maksimum pada saat perusahaan masuk ke pasar. 
Menurut Jogiyanto (2017:199) penilaian saham terdiri dari 3 jenis nilai yaitu nilai buku, nilai pasar, dan nilai intrinsik saham. Nilai buku merupakan nilai yang dihitung berdasarkan pembukuan perusahaan penerbit saham (emiten). Nilai pasar adalah nilai saham dipasar, yang ditunjukan oleh harga saham tersebut di pasar. Sedangkan nilai intrinsik dikenal juga sebagai nilai teoritis merupakan nilai saham yang sebenarnya, atau yang seharusnya terjadi. Penilaian tersebut merupakan informasi yang penting bagi investor dalam pengambilan keputusan investasi yang tepat. Investor ketika akan membeli atau menjual saham, akan membandingkan nilai intrinsik dengan nilai pasar saham yang bersangkutan.

Struktur modal merupakan gambaran dari bentuk proporsi finansial perusahaan yaitu antara modal yang dimiliki yang bersumber dari utang jangka panjang (long-term liabilities) dan modal sendiri (shareholders equity). Fahmi (2016:184) mengatakan struktur modal yang optimal bagi suatu perusahaan diartikan sebagai suatu struktur yang akan memaksimalkan harga saham perusahaan tersebut. Jika utang sesungguhnya berada dibawah target, maka pinjaman perlu ditambah. Jika rasio utang melampaui target, maka saham akan dijual. Kebijakan struktur modal merupakan trade off antara risk dan return. Apabila utang meningkat maka risk meningkat sehingga return pun akan meningkat. Apabila risk meningkat maka harga saham akan turun, dan apabila return meningkat maka saham akan naik.

Profitabilitas menurut Wiagustini (2014:76) adalah kemampuan perusahaan dalam memperoleh laba dapat juga digunakan sebagai alat untuk mengukur tingkat efektivitas dalam suatu perusahaan. Profitabilitas merupakan indikator 
untuk menilai sebuah perusahaan. Indikator ini juga dapat digunakan untuk mengukur kemampuan perusahaan untuk menghasilkan laba dan dapat membantu dalam menentukan efektivitas perusahaan dalam mengelola sumber saya yang dimiliki. Brigham dan Houston (2015:146) menyatakan bahwa rasio profitabilitas merupakan sekelompok rasio yang menunjukkan kombinasi dari pengaruh likuiditas, manajemen aset, dan utang pada hasil operasi.

Profitabilitas dalam penelitian ini diproksikan dengan return on total assets (ROA). ROA merupakan salah satu cara menghitung kinerja keuangan perusahaan dengan membandingkan laba bersih yang diperoleh perusahaan dengan total aset yang dimiliki oleh perusahaan. ROA menunjukkan seberapa banyak perusahaan telah memperoleh hasil atas sumber daya keuangan yang ditanamkan perusahaan sehingga digunakan ROA karena ROA dalam analisis merupakan salah satu teknik yang bersifat menyeluruh dan lazim digunakan untuk mengukur tingkat efektivitas dari keseluruhan operasi perusahaan.

Martini dkk. (2014) menyatakan bahwa sebuah ukuran perusahaan dapat didefinisikan sebagai penilaian seberapa besar atau kecil perusahaan yang akan diwakili oleh aset, jumlah penjualan, rata-rata total penjualan dan total aset ratarata. Dengan demikian, ukuran perusahaan adalah ukuran atau jumlah aset yang dimiliki oleh perusahaan. Hasnawati (2015) menyatakan bahwa ukuran perusahaan dapat mempermudah perusahaan dalam memperoleh dana dari pasar modal dan menentukan kekuatan tawar-menawar (bergaining power) dalam kontrak keuangan. 
Ukuran perusahaan yang besar akan lebih mudah memperoleh dana tambahan di pasar modal dibandingkan dengan perusahaan kecil. Kemudahan akses dialami oleh perusahaan besar yang berarti perusahaan besar memiliki fleksibilitas yang lebis besar pula. Bukti empiris menunjukkan bahwa ukuran perusahaan berhubungan positif dengan rasio utang dengan nilai buku ekuitas.

Ukuran perusahaan nantinya akan menggambarkan besar kecilnya suatu perusahaan yang dinyatakan dengan total aktiva atau total penjualan bersih. Semakin besar total aktiva maupun penjualan, maka semakin besar pula ukuran suatu perusahaan. Jadi dapat disimpulkan bahwa ukuran perusahaan menggambarkan besarnya aktiva yang dimiliki oleh perusahaan. Martini et al. (2014) menyebutkan bahwa pada umumnya, peneliti di Indonesia menggunakan total aktiva atau total penjualan sebagai acuan dari ukuran perusahaan. Ukuran perusahaan akan sangat penting bagi investor dan kreditor karena akan berhubungan dengan risiko investasi yang dilakukan.

Wiagustini (2014:286) menyatakan kebijakan dividen merupakan keputusan keuangan yang dilakukan oleh perusahaan setelah perusahaan beroperasi dan memperoleh laba. Kebijakan dividen menyangkut masalah penggunaan laba yang menjadi hak para pemegang saham atau keputusan apakah laba yang diperoleh perusahaan akan dibagikan kepada pemegang saham sebagai dividen atau ditahan guna pembiayaan investasi di masa yang akan datang. Kebijakan dividen berpengaruh terhadap aliran dana, struktur finansial, likuiditas perusahaan dan perilaku investor, sehingga kebijakan dividen merupakan salah satu keputusan penting dalam kaitannya dengan usaha untuk memaksimalkan nilai perusahaan. 
Profitabilitas dapat diartikan sebagai rasio terkait laba suatu perusahaan. Profitabilitas yang tinggi menunjukkan prospek perusahaan yang bagus sehingga memicu permintaan saham oleh investor (Novari dan Lestari, 2016). Rizqia et al. (2013) juga menyatakan bahwa keuntungan yang tinggi akan memberikan indikasi prospek perusahaan yang baik sehingga memicu investor untuk meningkatkan permintaan terhadap saham perusahaan sehingga mempengaruhi nilai perusahaan. Hal ini menjadi dasar pengambilan keputusan investor bahwa perusahaan dengan kemampuan perolehan laba lebih tinggi lebih mampu untuk meningkatkan kemakmuran dari pemegang saham. Maka dari itu, semakin tinggi rasio profitabilitas makan semakin tinggi pula nilai peusahaan.

Wahyuni et al. (2013) menyatakan bahwa profitabilitas berpengaruh positif dan signifikan terhadap nilai perusahaan. Pernyataan tersebut didukung oleh hasil penelitian dari Sabrin et al. (2016) yaitu profitabilitas memiliki pengaruh positif signifikan terhadap nilai perusahaan. Hasil tersebut juga serupa dengan hasil penelitian dari Hestinoviana et al. (2013), Mule et al. (2015) dan Martini et al. (2014) yang memperoleh hasil kenaikan laba perusahaan dapat meningkatkan nilai dari perusahaan tersebut.

$\mathrm{H}_{1}$ : Profitabilitas berpengaruh positif dan signifikan terhadap nilai perusahaan.

Struktur modal dapat digambarkan sebagai kombinasi antara utang dan ekuitas yang akan digunakan sebagai pendanaan kegiatan perusahaan. Menurut Febrianti (2012) perusahaan yang menggunakan utang pada umumnya memiliki nilai lebih tinggi pada nilai sebuah perusahaan dibandingkan dengan perusahaan yang tidak menggunakan utang. Utang dinyatakan sebagai salah satu sumber 
pendanaan perusahaan yang dianggap sangat mempengaruhi perubahan nilai perusahaan.Penggunaan utang yang tinggi menunjukkan perusahaan mampu memperoleh laba yang lebih tinggi dari perusahaan yang menggunakan utang lebih kecil dengan meminimalisir pengeluaran dari pajak penghasilan.

Isola (2014) menyatakan bahwa struktur modal berpengaruh positif terhadap nilai perusahaan. Hasil tersebut juga didukung oleh hasil yang diperoleh oleh Rassri dan Mustanda (2013) dan Kausar et al. (2014) yang menunjukkan bahwa struktur modal berpengaruh positif signifikan terhadap nilai perusahaan.

$\mathrm{H}_{2}$ : Struktur modal berpengaruh positif dan signifikan terhadap nilai perusahaan.

Ukuran perusahaan dapat digambarkan dengan total penjualan bersih atau total aktiva yang dimiliki suatu perusahaan. Semakin besar total aktiva atau total penjualan, maka semakin besar pula ukuran suatu perusahaan. Moeljadi (2014) menyatakan bahwa perusahaan dengan jumlah aktiva yang tinggi menunjukkan bahwa perusahaan memiliki arus kas positif dan dianggap memiliki prospek yang baik dalam kurun waktu yang relatif lama. Ukuran perusahaan akan mempengaruhi sebuah perusahaan dalam memperoleh dana dari luar perusahaan. Hal tersebut dapat meningkatkan minat investor sehingga menyebabkan naiknya harga saham perusahaan di pasar modal (Novari dan Lestari, 2016).

Prasetyorini (2013) dalam penelitiannya menyatakan bahwa ukuran perusahaan berpengaruh positif terhadap nilai perusahaan. Hal tersebut didukung oleh penelitian dari Hasnawati et al. (2015) yang menyatakan ukuran perusahaan berpengaruh positif terhadap nilai perusahaan. Maryam dan Adolkarim (2015) juga memperoleh bukti bahwa ukuran perusahaan berpengaruh positif terhadap 
nilai perusahaan. Berdasarkan kajian teori dan empiris tersebut maka dapat dirumuskan hipotesis sebagai berikut:

$\mathrm{H}_{3}$ : Ukuran perusahaan berpengaruh positif signifikan terhadap nilai perusahaan.

Kebijakan dividen adalah keputusan akhir yang harus diambil oleh seorang manajer keuangan untuk menentukan proporsi laba yang dibagikan kepada para pemegang saham yang bertujuan untuk meningkatkan kekayaan dan kinerja para pemegang saham (Fajaria, 2015). Pembagian dividen dianggap sebagai sinyal positif untuk menanamkan modal dikarenakan investor lebih suka pada return yang pasti pada investasinya. Dengan banyaknya investor yang membeli saham maka akan menaikkan harga saham sehingga meningkatkan nilai perusahaan.

Sartini dan Purbawangsa (2014) serta Fernandar dan Raharja (2012) menunjukkan bahwa kebijakan dividen berpengaruh positif terhadap nilai perusahaan. Adnyana dan Badjra (2014) juga menunjukkan bahwa kebijakan dividen berpengaruh positif terhadap nilai perusahaan. Hasil ini menunjukkan bahwa membagikan dividen akan meningkatkan nilai perusahaan.

$\mathrm{H}_{4}$ : Kebijakan dividen berpengaruh positif dan signifikan terhadap nilai perusahaan.

\section{METODE PENELITIAN}

Lokasi penelitian ini dilakukan pada perusahaan properti dan real estate yang tercantum di Bursa Efek Indonesia (BEI) yang dapat diakses melalui alamat website www.idx.co.id. Lokasi ini dipilih karena kemudahan dalam memperoleh data yang diperlukan dalam penelitian dan memiliki tingkat keakuratan.

Populasi dalam penelitian adalah seluruh perusahaan properti dan real estate di BEI pada periode 2014-2016, berjumlah 49 perusahaan properti dan real estate. 
Metode penentuan sampel dalam penelitian menggunakan teknik purposive sampling dimana teknik ini merupakan Teknik penentuan sampel dengan pertimbangan tertentu (Sugiyono, 2016:156). Pertimbangan yang digunakan adalah perusahaan yang terdaftar dan beroperasi secara penuh selama periode pengamatan yaitu dari tahun 2014-2016. Hasil penyaringan ditemukan bahwa 8 perusahaan terdaftar setelah tahun 2014 dan 1 perusahaan tidak mempublikasikan laporan keuangan pada periode pengamatan. Jadi jumlah sampel dalam penelitian ini adalah 40 perusahaan properti dan real estate yang terdaftar di BEI pada tahun 2014-2016.

Metode pengumpulan data dalam penelitian menggunakan metode observasi nonpartisipan yaitu peneliti tidak terlibat secara langsung, dan peneliti hanya mengamati secara independen (Sugiyono, 2016:236). Peneliti melakukan pengamatan dan pencatatan pada data-data terkait perusahaan properti dan real estate dengan cara mencatat, mengamati, serta mempelajari dari buku-buku, beberapa karya ilmiah seperti skripsi, jurnal baik itu internasional maupun nasional, dan mengakses internet pada situs tertentu yang relevan dengan penelitian.Teknik analisis data dalam penelitian ini menggunakan analisis regresi berganda dan pengolahan data akan menggunakan alat bantu yaitu berupa program Statistical Package for Social Science (SPSS).

\section{HASIL PENELITIAN DAN PEMBAHASAN}

Statistik deskriptif disajikan untuk informasi mengenai nilai minimum, nilai maksimum, nilai rata-rata (mean), dan nilai standar deviasi dari variabel penelitian. Hasil dari statistik deskriptif dapat dilihat pada Tabel 1 berikut. 
Tabel 1.

Hasil Analisis Statistik Deskriptif

\begin{tabular}{lccccc}
\hline & PBV & ROA & DER & SIZE & DPR \\
\hline$N$ & 120 & 120 & 120 & 120 & 120 \\
Mean & 1,37455 & 0,05343 & 0,73784 & 28,91175 & 0,07939 \\
Minimum & 0,120 & $-0,053$ & 0,031 & 25,162 & 0,000 \\
Maximum & 8,300 & 0,359 & 2,020 & 31,451 & 1,045 \\
Standard Deviation & 0,102792 & 0,055746 & 0,494206 & 1,484508 & 0,134204 \\
\hline
\end{tabular}

Sumber: Data diolah, 2018

Berdasarkan Tabel 1dapat dilihat jumlah pengamatan $(\mathrm{N})$ dalam penelitian ini sebanyak 120. Skor minimum dalam tabel menunjukkan nilai terendah dari data penelitian, sedangkan skor maksimum dalam tabel menunjukkan nilai tertinggi dari data penelitian. Mean digunakan untuk mengukur nilai rata-rata dari data, dan standard deviation menunjukkan simpangan baku.

PBV dari 120 sampel mempunyai rentang nilai dari 0,12 sampai 8,3 kali. Nilai terendah sebesar 0,12 kali dimiliki oleh perusahaan Ristia Bintang Mahkotasejati Tbk pada tahun 2015 dan nilai tertinggi sebesar 8,3 kali dimiliki oleh Plaza Indonesia Realty Tbk pada tahun 2016. Nilai rata-rata PBV sebesar 1,374 dengan standar deviasi sebesar 1,126.

ROA dari 120 sampel mempunyai rentang nilai dari $-5,3$ persen sampai 35,9 persen. Nilai terendah sebesar $-5,3$ persen dimiliki oleh Metro Realty Tbk pada tahun 2015 dan nilai tertinggi sebesar 35,9 persen dimiliki oleh Fortune Mate Indonesia Tbk pada tahun 2016. Nilai rata-rata ROA sebesar 5,34 persen dengan standar deviasi sebesar 5,57.

DER dari 120 sampel mempunyai rentang nilai dari 0,31 sampai 2,02. Nilai terendah sebesar 0,31 dimiliki oleh Eureka Prima Jakarta Tbk pada tahun 2016 dan nilai tertinggi sebesar 2,02 dimiliki oleh Cowell Development Tbk pada tahun 2015. Nilai rata-rata DER sebesar 0,738 dengan standar deviasi sebesar 0,494. 
SIZE dari 120 sampel mempunyai rentang nilai dari 25,16 sampai 31,45. Nilai terendah sebesar 25,16 dimiliki oleh Metro Realty Tbk pada tahun 2016 dan nilai tertinggi sebesar 31,45 dimiliki oleh Lippo Karawaci Tbk pada tahun 2016. Nilai rata-rata SIZE sebesar 28,912 dengan standar deviasi sebesar 1,484.

DPR dari 120 sampel mempunyai rentang nilai dari 0 persen sampai 104,5 persen. Nilai terendah sebesar 0 persenterdapat pada 58 pengamatan dan nilai tertinggi sebesar 104,5 persen dimiliki oleh Plaza Indonesia Realty Tbk pada tahun 2016. Nilai rata-rata DPR sebesar 7,94 persen dengan standar deviasi

\begin{tabular}{|c|c|c|c|}
\hline No. & Variabel & Koefisien Regresi & Sig \\
\hline 1 & ROA & 5,182 & 0,000 \\
\hline 2 & DER & 0,035 & 0,816 \\
\hline 3 & Size & $-0,017$ & 0,735 \\
\hline 4 & DPR & 5,790 & 0,000 \\
\hline \multicolumn{3}{|c|}{ R Square $=0,630$} & $F=49,016$ \\
\hline \multicolumn{3}{|c|}{ Adjusted R Square $=0,617$} & $\operatorname{Sig}=0,000$ \\
\hline
\end{tabular}
sebesar 0,134 .

Analisis regresi linear berganda digunakan untuk mengetahui arah dan besarnya pengruh profitabilitas, struktur modal, ukuran perusahaan dan kebijakan dividen terhadap nilai perusahaan property dan real estate di BEI tahun 20142016 dengan menggunakan SPSS.Hasil regresi linear berganda untuk penelitian ini dapat dilihat pada Tabel 2 berikut ini:

Tabel 2.

\section{Hasil Ringkasan Analisis Regresi Linear Berganda} Sumber: Data diolah, 2018

Berdasarkan Tabel 2, maka dapat dibentuk persamaan regresi linear berganda pada penelitian ini yaitu sebagai berikut:

$$
Y=1,096+5,182 X_{1}+0,035 X_{2}-0,017 X_{3}+5,790 X_{4}
$$

Keterangan:

$\mathrm{Y}=$ Nilai Perusahaan 
$\mathrm{X}_{1}=$ Profitabilitas

$\mathrm{X}_{2}=$ Struktur Modal

$\mathrm{X}_{3}=$ Ukuran Perusahaan

$\mathrm{X}_{4}=$ Kebijakan Dividen

Berdasarkan persamaan regresi linear berganda diatas maka dapat dikatakan bahwa variabel profitabilitas yang diproksikan dengan ROA menunjukkan probabilitas tingkat signifikansi sebesar $0,000 \quad(<0,050)$ dan koefisien regresi sebesar 5,182. Hasil ini menunjukkan bahwa hipotesis diterima yaitu profitabilitasberpengaruh positif dan signifikan terhadap nilai perusahaan. ROA dapat mempengaruhi PBV pada perusahaan properti dan real estate. Semakin tinggi ROA menunjukkan tingkat efisien perusahaan dalam memperoleh laba juga tinggisehingga PBV perusahaan meningkat.

Profitabilitas yang tinggi dapat menarik investor untuk berinvestasi pada sebuah perusahaan. Profitabilitas perusahaan yang tinggi menunjukkan bahwa perusahaan tersebut mampu menggunakan sumber daya yang dimiliki perusahaan untuk menghasilkan laba dengan efektif. Profitabilitas yang tinggi menunjukkan kepada investor bahwa perusahaan mampu meningkatkan kemakmuran para pemegang saham dengan dibagikannya return melalui dividen, sehingga investor tertarik untuk membeli saham perusahaan tersebut. Permintaan terhadap saham meningkat membuat harga saham akan naik. Harga saham perusahaan yang naik akan berdampak pada naiknya nilai perusahaan, dengan demikian profitabilitas dapat menjadi sinyal positif bagi investor.

Berdasarkan signalling theory sebuah perusahaan dengan sukarela akan melaporkan informasi ke pasar modal tanpa adanya dorongan dari pemerintah, 
informasi ini ditujukan untuk mempertahankan minat dari investor agar tidak terjadi asimetri informasi antara pihak perusahaan dengan luar persuahaan (Brigham and Houston, 2015:186).Penyampaian informasi mengenai profitabilitas suatu perusahaan merupakan sebuah sinyal bagi perusahaan. Profitabilitas yang tinggi dan stabil akan menjadi sinyal positif bagi investor terkait dengan kinerja perusahaan (Rizqia, 2013). Hasil ini didukung dengan penelitian Wahyuni dkk. (2013) yang menyatakan bahwa profitabilitas berpengaruh positif terhadap nilai perusahaan. Begitu pula penelitian yang dilakukan oleh Nurhayati (2013) dan Martini et. al. (2014) yang memperoleh bukti bahwa kenaikan laba yang diperoleh perusahaan dapat meningkatkan nilai sebuah perusahaan.

Hasil pengujian variabel struktur modal yang diproksikan dengan DER menunjukkan probabilitas tingkat signifikansi sebesar $0,816 \quad(>0,050)$ dan koefisien regresi 0,035. Hasil ini memperlihatkan bahwa DER berpengaruh positif namun tidak signifikan pada PBV perusahaan properti dan real estate yang terdaftar di BEI sehingga hipotesis kedua ditolak. Hasil ini menunjukkan bahwa peningkatan DER yang menunjukkan penggunaan utang perusahaan tidak diikuti dengan peningkatan PBV yang signifikan sehingga DER bukan merupakan faktor utama bagi investor dalam melakukan investasi.

Penggunaan utang yang tinggi selain memberikan dampak positif, juga dapat memberikan dampak negatif. Risiko yang dihadapi perusahaan yang menggunakan utang yang tinggi pada modal perusahaan sangatlah tinggi. Utang yang tinggi, jika tidak dapat dipenuhi dapat membuat perusahaan terancam pailit. Risiko tersebut dapat memberikan sinyal negatif kepada investor. Dampak positif 
dan negatif pada penggunaan utang suatu perusahaan membuat penggunaan utang tidak bisa dijadikan suatu pertimbangan dalam berinvestasi, sehingga struktur modal tidak dapat memberi sinyal kepada investor dalam berinvestasi, sebagai perbandingan pada tahun 2015 Agung Podomoro Tand Tbk memiliki DER sebesar 1,71 dan PBV sebesar 0,75, lebih kecil dari PBV Jaya Real Property yaitu sebesar 2,47 dengan DER sebesar 0,83. Sedangkan Ristia Bintang Mahkotasejati Tbk memiliki DER sebesar 0,08 dan PBV 0,12 lebih kecil dari PBV Cowell Development Tbk yaitu sebesar 1,69 dengan DER sebesar 2,02. Hasil penelitian ini didukung oleh Ayem dan Nugroho (2016) yang menyatakan bahwa struktur modal berpengaruh positif tidak signifikan terhadap nilai perusahaan.

Hasil pengujian variabel ukuran perusahaan yang diproksikan dengan SIZE menunjukkan probabilitas taraf signifikansi sebesar $0,735(>0,050)$ dan koefisien regresi sebesar -0,017. Hasil ini menunjukkan bahwa SIZE berpengaruh negatif dan tidak signifikan pada PBV perusahaan properti dan real estate yang terdaftar di BEI, sehingga hipotesis ketiga ditolak. Hasil ini menunjukkan bahwa perubahan SIZE tidak diikuti dengan perubahan pada PBV perusahaan properti dan real estate sehingga SIZE bukan merupakan faktor bagi investor dalam melakukan investasi. Hasil ini sejalan dengan hasil penelitian sebelumnya yang dilakukan oleh Pantow dkk. (2015) yang menyatakan ukuran perusahaan berpengaruh negatif dan tidak signifikan terhadap nilai perusahaan.

Berdasarkan hasil penelitian, besar kecilnya ukuran perusahaan tidak mampu memengaruhi nilai perusahaan. Ukuran bukan menjadi faktor utama bagi investor dalam menilai suatu perusahaan. Semakin besar ukuran perusahaan tidak 
menjamin laba yang diperoleh juga semakin besar, begitupun sebaliknya semakin kecil perusahaan belum tentu perusahaan tersebut memperoleh laba yang kecil. Sebagai perbandingan, pada tahun 2016 Bekasi Fajar Industrial Estate Tbk memiliki total aset sebesar 5.205 milyar dan PBV sebesar 0,74, lebih besar dari PBV Bakrieland Development Tbk sebesar 0,33 dengan total aset 14.063 milyar. Sedangkan Summarecon Agung Tbk memiliki total aset sebesar 20.810 milyar dan PBV sebesar 2,48, lebih besar dari PBV Suryamas Dutamakmur Tbk yaitu 0,15 dengan total aset 3.098 milyar. Dewi dan Badjra (2017) menyatakan ukuran perusahaan belum dapat menjamin bahwa dengan jumlah aset yang besar dapat membuat kemakmuran pemegang saham menjadi meningkat, karena pihak internal perusahaan belum dapat menjamin dengan jumlah aset yang besar akan menghasilkan keuntungan maksimal yang diharapkan investor. Perusahaan yang besar belum tentu menghasilkan arus kas positif secara terus menerus. Menurut Suwardika dan Mustanda (2017), investor lebih lebih melihat aspek-aspek seperti kinerja perusahaan yang terlihat pada laporan keuangan perusahaan, nama baik perusahaan, serta kebijakan dividen sebelum memutuskan untuk menanamkan dananya pada perusahaan tersebut.

Hasil penelitian menunjukkan variabel kebijakan dividen yang diproksikan dengan DPR mempunyai probabilitastingkat signifikansi sebesar $0,000(<0,050)$ dan koefisien regresi sebesar 5,790. Hasil ini menunjukkan bahwa hipotesis keempat diterima yaitu kebijakan dividen berpengaruh positif dan signifikan terhadap nilai perusahaan. KenaikanDPR menunjukkan naiknya dividen yang 
akan dibagikan menunjukkan PBV perusahaan properti dan real estate meningkat sehingga.

Hasil ini menunjukkan bahwa kebijakan dividen merupakan faktor yang sangat dipertimbangkan oleh investor dalam menilai suatu perusahaan untuk berinvestasi. Investor cenderung lebih menyukai return yang pasti pada investasinya. Perusahaan yang membagikan dividen menunjukkan perusahaan memperoleh laba serta mampu untuk memakmurkan para pemegang saham. Pembagian dividen dapat memberikan sinyal positif terhadap investor sehingga investor berminat untuk membeli saham perusahaan tersebut. Meningkatnya permintaan terhadap saham perusahaan membuat harga saham akan naik, sehingga nilai perusahaan juga akan naik. Hasil penelitian serupa juga dinyatakan oleh Ayem dan Nugroho (2016) yang menyatakan bahwa semakin besar dividen yang diterima pemegang saham, maka semakin besar pula nilai suatu perusahaan. Hasil tersebut juga didukung oleh penelitian Priya dan Mohanasundari (2016), Winarto (2015), Adnyana dan Badjra (2014) serta Sartini dan Purbawangsa (2014) bahwa kebijakan dividen berpengaruh positif dan signifikan terhadap nilai perusahaan.

\section{SIMPULAN DAN SARAN}

Berdasarkan hasil analisis dan pembahasan yang telah dilakukan pada bab sebelumnya, maka dapat disimpulkan bahwa meningkatnya profitabilitas menyebabkan nilai perusahaan naik menunjukkan profitabilitas memberikan sinyal positif kepada investor dan menjadi faktor yang harus diperhatikan oleh manajemen perusahaan.Perubahan struktur modal tidak diikuti dengan perubahan 
nilai perusahaan menunjukkan struktur modal tidak dapat memberikan sinyal kepada investor.Perubahan ukuran perusahaan tidak diikuti dengan perubahan nilai perusahaan menunjukkan ukuran perusahaan tidak dapat memberikan sinyal kepada investor. Meningkatnya kebijakan dividen menyebabkan nilai perusahaan naik menunjukkan bahwa kebijakan dividen memberikan sinyal positif kepada investor dan menjadi faktor yang harus diperhatikan oleh manajemen perusahaan.

Berdasarkan simpulan, maka saran yang dapat diberikan bagi pihak investor dan perusahaan diharapkan untuk lebih memperhatikan faktor-faktor yang berdampak bagi nilai perusahaan yaitu profitabilitas dan kebijakan dividen. Hal ini dikarenakan profitabilitas dan kebijakan dividen terbukti berpengaruh signifikan terhadap nilai perusahaan sehingga dapat memberikan sinyal bagi investor.Bagi peneliti selanjutnya dapat meneliti kembali pengaruh keempat variabel tersebut terhadap nilai perusahaan dan juga dapat ditambah dengan variabel lain yang dapat mempengaruhi nilai perusahaan seperti aktiva tidak berwujud dan likuiditas, serta dapat menambah periode waktu penelitian agar dapat memperoleh hasil yang lebih baik.

\section{REFERENSI}

Ayem, Sri, dan Ragli Nugroho. (2016). Pengaruh Profitabilitas, Struktur Modal, Kebijakan Deviden, dan Keputusan Investasi Terhadap Nilai Perusahaan. Jurnal Akuntansi. 4(1), hal.31-39.

Brigham, E. F. dan J. F. Houston. (2015). Manajemen Keuangan. Edisi Sebelas. Jakartaa: Salemba Empat.

Bursa Efek Indonesia. (2017). Ringkasan Kinerja Perusahaan Tercatat. www.idx.co.id, diakses pada tanggal 14 November 2017.

Chen, Li-Ju and Shun-Yu Chen. (2011). The Influence of Profitability on Firm Value with Capital Structure As The Mediator And Firm Size And 
Industry As Moderators. Invesment Management and Financial Innovations. 8(3), hal.121-129.

Dewi, A. A. A. Kemara, dan I. B Badjra. (2017). Pengaruh Profitabilitas, Aktiva Tidak Berwujud, Ukuran Perusahaan, dan Struktur Modal Terhadap Nilai Perusahaan. E-Jurnal Manajemen Universitas Udayana. 6(4), hal.21612190.

Eko, Prasetia Ta'dir, Parengkuan Tommy, dan Ivone S. Taerang. (2014). Struktur Modal, Ukuran Perusahaan dan Risiko Perusahaan Terhadap Nilai Perusahaan Otomotif yang Terdaftar di BEI. Jurnal EMBA. 2(2), hal.879889.

Fahmi, Irham. (2016). Pengantar Manajemen Keuangan. Bandung: Alfabeta.

Febrianti, Meiriska. (2012). Faktor-faktor yang Mempengaruhi Nilai Perusahaan pada Industri Pertambangan di Bursa Efek Indonesia. Jurnal Bisnis dan Akuntansi. 14(2), hal. 141-156.

Gayatri, N. L. P. Rassri dan I Ketut Mustanda. (2014). Pengaruh Struktur Modal, Kebijakan Dividen dan Keputusan Investasi Terhadap Nilai Perusahaan. E-Jurnal Manajemen Universitas Udayana. 3(6), hal.1700-1718.

Hanafi, Mamduh M. (2016). Manajemen Keuangan, Edisi Kedua. Yogyakarta: BPFE.

Hasnawati, S. dan Sawir Agnes. (2015). Keputusan Keuangan, Ukuran Perusahaan, Struktur Kepemilikan, dan Nilai Perusahaan Publik di Indonesia. Jurnal Manajemen dan Kewirausahaan. 17(1), hal.65-75.

Hestinoviana, Vidyanita, Suhadak, and Siti Ragil Handayani. (2013). The Influence of Profitability, Solvability, Asset Growth, and Sales Growth Toward Firm Value (Empirical Study on Mining Companies Which Listed on Indonesia Stock Exchange. Jurnal Administrasi Bisnis. 4(1), pp: 1-11.

Husnan, Suad dan Enny Pudjiastuti. (2012). Dasar-dasar Manajemen Keuangan, Edisi Keenam. Yogyakarta: UPP STIM YKPN.

Isola, Adedoyin. (2014). Capital Structure and The Value of The Firm: Evidence From The Nigeria Banking Industry. Journal of Accounting and Management. 4(1), hal.31-41.

Jogiyanto, Hartono. (2017). Teori Portofolio dan Analisis Investasi. Edisi Kesebelas. Yogyakarta: BPFE. 
Kausar, A., Nazir, Sajid M., Butt, dan Awais. (2014). Capital Structure and Firm Value: Empirical Evidence from Pakistan. Asian Journal of Research in Economics and Finance. 1(1), hal.11-22.

Laksitaputri, Iriena Maharani. (2012). Analisis Faktor-Faktor yang Mempengaruhi Nilai Perusahaan dengan Profitabilitas sebagai Variabel Intervening (Studi pada Perusahaan Manufaktur yang Terdaftar di Bursa Efek Indonesia periode 2008-2010). Jurnal Bisnis Strategi. 21(2), hal. 1-17.

Mardiyati, Umi., Gatot Nazir Ahmad, dan Ria Putri. (2012). Pengaruh Kebijakan Dividen, Kebijakan Hutang dan Profitabilitas terhadap Nilai Perusahaan Manufaktur yang Terdaftar di Bursa Efek Indonesia (BEI) periode 20052010. Jurnal Riset Manajemen Sains Indonesia (JRMSI). 3(1), hal: 1-17.

Martini, Ni Nyoman, Moeljadi, Djumahir, and Djazuli Atim. (2014). Factors Affecting Firm Value of Indonesia Public Manufacturing Frim. International Journal of Business and Management Invention. 3(2), hal.35-44.

Maryam, Alhani F. dan Moghadam Adolkarim. (2015). The Effect of Capital Structure on Firm Value, The Rate of Return on Equity and Earnings Per Share of Listed Companies in Tehran Stock Exchange. Research Journal of Finance and Accounting. 6(15), hal.50-58.

Moeljadi. (2014). Factors Affecting Firm Value The Oretical Study on Public Manufacturing Firm in Indonesia. South East Asia Journal of Contemporary Business, Economics and Law. 5(2), hal.6-15.

Mule, R.K., Mukras Suleiman M., and Nzioka Mutunga Onesmus. (2015). Coroporate Size, Profitability, and Market Value: An Econometric Panel Analysis of Listed Firms in Kenya. European Scientific Journal. 11(13), hal.376-396.

Novari, P. Mikhy, dan P. Vivi Lestari. (2016). Pengaruh Ukuran Perusahaan, Leverage, Dan Profitabilitas Terhadap Nilai Perusahaan Pada Sektor Properti Dan Real Estate. E-Jurnal Manajemen Universitas Udayana. 5(9), hal.5671-5694.

Nurhayati, M. (2013). Profitabilitas, Likuiditas, dan Ukuran Perusahaan Pengaruhnya Terhadap Kebijakan Dividen dan Nilai Perusahaan Sektor Jasa. Jurnal Keuangan dan Bisnis. 5(2), hal. 144-153.

Obradovich, John, dan Amarjit Gill. (2013). The Impact of Corporate Governance and Financial Leverage on the Value of American Firms. International Research Journal of Finance and Economics. 9(1), hal.1-14. 
Pantow, Mawar Sharon R., Sri Murni, Irvan Trang. (2015). Analisa Pertumbuhan Penjualan, Ukuran Perusahaan, Return On Asset, dan Struktur Modal Terhadap Nilai Perusahaan Yang Tercatat Di Indeks LQ 45. Jurnal Riset Ekonomi, Manajemen, Bisnis dan Akuntansi. 3(1), hal.961-971.

Pramana, IGNAD, dan I Ketut Mustanda. (2016). Pengaruh Profitabilitas dan Size Terhadap Nilai Perusahaan Dengan CSR Sebagai Variabel Pemoderasi. EJurnal Manajemen Universitas Udayana, 5(1), hal.561-594.

Prasetyorini, Bhekti F. (2013). Pengaruh Ukuran Perusahaan, Leverage, Price Earning Ratio dan Profitabilitas Terhadap Nilai Perusahaan. Jurnal Ilmu Manajemen. 1(1), hal.183-196.

Priatinah, D., dan P. A. Kusuma. (2012). Pengaruh Return On Investment (ROI), Earnings Per Share (EPS), dan Dividend Per Share (DPS) Terhadap Harga Saham Perusahaan Pertambangan yang Terdaftar di Bursa Efek Indonesia (BEI) Periode 2008-2009. Jurnal Nominal. 1(1), hal.50-64.

Priya, P. Vidhya, dan M. Mohanasundari. (2016). Dividend Policy and Its Impact on Firm Value: A Review of Theories and Empirical Evidence. Journal of Management Sciences and Technology. 3(3), hal.59-69.

Putra, A. A. N. Dharma Adi dan P. Vivi Lestari. (2016). Pengaruh Kebijakan Dividen, Likuiditas, Profitabilitas dan Ukuran Perusahaan Terhadap Nilai Perusahaan. E-Jurnal Manajemen Universitas Udayana. 5(7), hal.4044 4070 .

Rizqia, A., Dwita, Aisjah, S., and Sumiati. (2013). Efect of Managerial Ownership, Financial Leverage Profitability, Firm Size, and Investment Opportunity on Dividend Policy and Firm Value. Research Journal of Finance and Accounting. 4(11), hal.120-130.

Sabrin, Buyung Sarita, Dedy Takdir dan Sujono. (2016). The Effect of Profitability on Firm Value in Manufacturing Company at Indonesia Stock Exchange. The International Journal Of Engineering And Science. 5(10), hal. 81-89.

Sartini, Luh Putu Novita dan I. B. Anom Purbawangsa. (2014). Pengaruh Keputusan Investasi, Kebijakan Dividen, serta Keputusan Pendanaan Terhadap Nilai Perusahaan Manufaktur di Bursa Efek Indonesia. Jurnal Manajemen, Strategi Bisnis dan Kewirausahaan. 8(2), hal.81-90.

Siahaan, Fadjar O. P..(2013). The Effect of Good Corporate Governance Mechanism, Leverage, and Firm Size on Firm Value. International Journal on Business Review (GBR). 2(4), hal.137-142. 
Sugiyono. (2016). Metode Penelitian Bisnis. Bandung:Alfabeta.

Sutrisno. (2016). Capital Structure Determinants and Their Impact on Firm Value: Evidence From Indonesia. Economic World. 4(4), hal.179-186.

Suwardika, I. N Agus, dan I Ketut Mustanda. (2017). Pengaruh Leverage, Ukuran Perusahaan, Pertumbuhan Perusahaan, dan Profitabilitas Terhadap Nilai Perusahaan pada Perusahaan Properti. E-Jurnal Manajemen Universitas Udayana. 6(3), hal.1248-1277.

Triagustina, L., Sukarmanto E., dan Heliana. (2014). Pengaruh ROA dan ROE Terhadap Nilai Perusahaan Pada Perusahaan Manufaktur Subsektor Makanan dan Minuman Yang Terdaftar Di BEI. Akuntansi, Gelombang 2. hal.28-34.

Van Horne, James C. dan John M. Wachowicz. (2012). Prinsip-prinsip Manajemen Keuangan, Edisi 13. Jakarta: Salemba Empat.

Wahyuni, Tri, Endang Ernawati, W. R. Murhadi. (2013). Faktor-Faktor yang Mempengaruhi Nilai Perusahaan di Sektor Property, Real Estate \& Building Construction yang Terdaftar di BEI Periode 2008-2012. Jurnal Ilmiah Mahasiswa Universitas Surabaya. 2(1), hal. 1-18

Wiagustini. (2014). Dasar-Dasar Manajemen Keuangan. Edisi Kedua. Denpasar: Udayana University Press.

Wijaya, Bayu Irfandi dan I.B. Panji Sedana. (2015). Pengaruh Profitabilitas Terhadap Nilai Perusahaan (Kebijakan Dividen dan Kesempatan Investasi Sebagai Variabel Mediasi). E-Jurnal Manajemen Universitas Udayana, 4(12), hal.4477-4500.

Winarto, Jacinta. (2015). The Determinants of Manufacturer Firm Value in Indonesia Stock Exchange. International Journal of Information, Business and Management. 7(4), hal.323-349. 